\title{
"HOURS CONTINUING LONG" AS WHITMAN'S REWRITING OF SHAKESPEARE'S SONNET 29
}

\author{
Nils Clausson
}

"Poetry is made out of other poems." — Northrop Frye

"Any poem is an inter-poem, and any reading of a poem is an inter-reading. A poem is not writing, but rewriting, and though a strong poem is a fresh start, such a start is a starting again." - Harold Bloom

When Horace Traubel asked Walt Whitman if Keats's poetry "suggest[ed] the Greek" to him, Whitman replied, “Oh, no; Shakespeare's sonnets, not the Greek. You know, the sonnets are Keats and more-all Keats was, then a vast sum added. For superb finish, style, beauty, I know of nothing in all literature to come up to these sonnets. They have been a great worry to the fellows, and to me, too-a puzzle, the sonnets being of one character, the plays of another." the sonnets at first seems inconsistent with Whitman's poetics. Indeed, as the bardic voice of American individuality, expansiveness and freedom, Whitman surely embodies everything in poetry that is antithetical to the tight, restrictive form of the sonnet. Although he did write the most popular of his poems during his lifetime, "O Captain! My Captain!," in the ballad measure common in many folk songs of his day, Whitman rejected most traditional metrical forms. It seems impossible to imagine him saying, with Wordsworth, that "'twas pastime to be bound / Within the Sonnet's scanty plot of ground." It is almost as difficult to imagine Whitman writing a sonnet as to imagine him composing Leaves of Grass in heroic couplets.

And yet write sonnets he did, at least of a sort. He referred to "Live Oak, with Moss," the sequence of twelve homoerotic love poems later incorporated into the "Calamus" cluster, as "A Cluster of Poems, Sonnets expressing the thoughts, pictures, aspirations." 2 Since they obviously are not sonnets in the strict definition of that term, why did Whitman call them sonnets? What attractions did the sonnet form hold for him? Critics have been almost unanimously silent on these questions. Alan Helms detects an echo of Shakespeare's Sonnet 121 ("'Tis better to be vile than vile esteemed") in the eighth poem in the series, "Hours Continuing 
Long." 3 And in his biography of Whitman, Justin Kaplan describes the series of "Calamus" poems as "a narrative sequence, like Shakespeare's [sonnets], that dramatizes - not necessarily recounts - a passionate attachment to a younger man." ${ }^{4}$ But for both Helms and Kaplan, the similarities between Shakespeare's sonnets and the "Calamus" poems are confined to the similar subject matter (the male speakers' relationships with a younger man) rather than to similarities in form.

I am convinced that, at least in "Hours Continuing Long," Whitman was doing more than echoing Sonnet 121 or drawing a general parallel between his sequence of poems about male relationships and Shakespeare's sonnets addressed to a beautiful youth. There is substantial textual evidence to suggest that in composing "Hours Continuing Long," Whitman clearly modeled both the form and the content of his "sonnet" on Shakespeare's Sonnet 29 " "When in disgrace with fortune and men's eyes"). While it is obviously not a typical sonnet whose form has been inexplicably overlooked by critics, "Hours Continuing Long" is certainly a reply to Shakespeare's sonnet and a transformation of the traditional sonnet into a new form. Whitman wrote his poem as a deliberate response to Shakespeare's antecedent poem, and he expected his readers to be aware not only of the similarities between the two poems (enforced by numerous verbal echoes and structural parallels) but alsoand more importantly - of the significant differences.

Of course, we cannot be aware of the deliberately deviant form of Whitman's "sonnet" unless we read it in the context of conventional sonnets, and specifically of Shakespeare's Sonnet 29. The intertextual relationships between Whitman's "sonnet" and Shakespeare's Sonnet 29 suggest that Whitman is a more "traditional" poet than is usually acknowledged, though certainly not in the pejorative sense of that term. In an anonymous interview in 1879 , Whitman said, "As we are a new nation with almost a new geography, and a new spirit, the expression of them will have to be new. In form, in combination we shall take the same old font of type, but what we set up will never have been set up before. It will be the same old font that Homer and Shakespeare used, but our use will be new" (Myerson, 15). Although this remark can, and usually is, taken as a manifesto of the new American poetic that Whitman advocated and embodied, it certainly does not imply a complete break with tradition. Whitman's claim that the expression of the American spirit will be new while the form will be "the same old font that Homer and Shakespeare used" could be read as an anticipation of T. S. Eliot's doctrine of the relationship between tradition and the individual talent. That relationship, or at least Whitman's idea of it, is illustrated by the complex relationship between "Hours Continuing Long" and the Shakespearean poem it both imitates and re-forms. ${ }^{5}$ 
Whitman does more than echo Sonnet 29-he models his own poem on its structure. Sonnet 29 is, in one important way, closer to the structure of the Italian than the English sonnet. It consists of two parts: an octave in which the speaker describes an "outcast state" of mind very similar to that of Whitman's and a sestet in which he is rescued from "these thoughts" by "remember[ing]" the "sweet love" of the beautiful young man to whom the sonnet is addressed. "Hours Continuing Long" consists of twelve lines divided into two parts. The first six and a half lines, which describe Whitman's forsaken state occasioned by a failed relationship, resemble the octave of a traditional sonnet; and the next five and a half lines, consisting of a series of questions in which Whitman wonders whether there are "other men" like him, or even "one other like him," are the counterpart of the sestet. Note that the "turn" comes not at the end of the sixth line but in the seventh, after the dash. Thus the division between the two parts retains the imbalance - six and a half lines vs. five and a half - characteristic of the Petrarchan sonnet. Whitman's "sonnet," then, follows the bi-partite structure of the Italian sonnet, and it is that structure that Whitman is borrowing, not such external markers of the form as a specific number of lines or a particular rhyme scheme. Even unconventional sonnets, whatever their rhyme scheme or number of lines, retain this essential structural feature of the form, which is why an unrhymed sonnet is conceivable while an unrhymed fourteen-line poem with no equivalent of the sonnet's "turn" is just a fourteen-line poem.

But it is not just the bi-partite sonnet form (two asymmetrical parts) and the situation of a male speaker expressing his love for a man that "Hours Continuing Long" shares with Sonnet 29. Whitman's "sonnet" contains numerous verbal echoes of Shakespeare's, so many in fact that they cannot be accidental. Here are the two poems:

\section{XXIX}

When in disgrace with fortune and men's eyes,

I all alone beweep my outcast state,

And trouble deaf heav'n with my bootless cries,

And look upon myself and curse my fate,

Wishing me like to one more rich in hope,

Featured like him, like him with friends possessed,

Desiring this man's art, and that man's scope,

With what I most enjoy contented least;

Yet in these thoughts myself almost despising,

Haply I think on thee, and then my state,

Like to the lark at break of day arising

From sullen earth, sings hymns at heaven's gate;

For thy sweet love rememb'red such wealth brings

That then I scorn to change my state with kings. ${ }^{6}$ 
Hours continuing long, sore and heavy-hearted,

Hours of the dusk, when I withdraw to a lonesome and unfrequented spot, seating myself, leaning my face in my hands;

Hours sleepless, deep in the night, when I go forth, speeding swiftly the country roads, or through the city streets, or pacing miles and miles, stifling plaintive cries;

Hours discouraged, distracted — for the one I cannot content myself without, soon I saw him content himself without me;

Hours when I am forgotten, ( $\mathrm{O}$ weeks and months are passing, but I believe I am never to forget!)

Sullen and suffering hours! (I am ashamed-but it is useless-I am what I am;)

Hours of my torment-I wonder if other men ever have the like, out of the like feelings?

Is there even one other like me-distracted - his friend, his lover, lost to him?

Is he too as I am now? Does he still rise in the morning, dejected, thinking who is lost to him? and at night, awaking, think who is lost?

Does he too harbor his friendship silent and endless? harbor his anguish and passion?

Does some stray reminder, or the casual mention of a name, bring the fit back upon him, taciturn and deprest?

Does he see himself reflected in me? In these hours, does he see the face of his hours reflected? ${ }^{7}$

The parallels are striking. The long "when" clause that governs Shakespeare's octave is paralleled by Whitman's two "when" clauses: "when I withdraw ..." and "when I go forth ...." Whitman's "plaintive cries" echo "Shakespeare's "bootless cries," with the word "cries" appearing at the end of line three of both poems. In the second line of his poem, Whitman "withdraw[s]" to a "lonesome and unfrequented spot," and Shakespeare's speaker (also in the second line) "all alone beweep[s]" his "outcast fate." Whitman says that he is "discouraged, distracted," for the man that he "cannot content [him] self without" can now "content himself without" Whitman; Shakespeare's speaker says that with what he does "most enjoy" he is "contented least." Whitman refers to the "Sullen and suffering hours" when he is "forgotten"; Shakespeare's speaker concludes the poem with a description of the joy arising from his friend's "sweet love rememb'red." In addition, Whitman echoes Shakespeare's choice of the word "sullen." Shakespeare's lark "arising / From sullen earth sings hymns at heaven's gate"; the "discouraged" Whitman describes himself as "Sullen and suffering." There is also the parallel use of the words "thinking" and "think." Shakespeare's speaker says, "Haply I think on thee," and Whitman wonders if there is a double of himself, suffering similarly: "Does he still rise in the morning, dejected, thinking who is lost to him? and at night, awaking, think who is lost?" Whitman's choice of the words "rise," "morning," and "awaking" were likely suggested too 
by Shakespeare's line, "Like to the lark at break of day arising." And finally, Shakespeare's speaker confesses that he has reached the point of "almost despising" himself, while Whitman says he is "ashamed" of himself - not a verbal echo but a synonym used to describe a similar psychological state.

When these numerous verbal echoes are considered along with the similar situations of the two speakers and the bi-partite structure of the two poems, the only reasonable conclusion to draw is that Whitman is not simply alluding to Shakespeare's Sonnet 29 but is quite deliberately modeling his poem on one of Shakespeare's most popular and frequently reprinted sonnets - one that he can safely assume many of his readers would be familiar with. An obvious reason for Whitman's imitation of Sonnet 29 is that Shakespeare's famous poem about a man addressing a beautiful youth provides a literary precedent, and hence a justification, for the subject matter of his later poem. But in calling attention to these echoes and parallels, it is important to recognize that Whitman is not merely imitating Shakespeare's poem to align himself with the greatest poet in the English language. Whitman is responding to the poem and rewriting it by setting up a contrast between his new "sonnet" and Shakespeare's old one. Whitman's deliberate echoes of Sonnet 29 create expectations in the reader about the direction the poem will take-expectations that the poem then significantly fails to fulfill. The first thing to notice is that Whitman, in contrast to Shakespeare, reverses the usual structure of the Renaissance Italian sonnet and the English sonnets written in imitation of it. A frequent pattern of the form is to pose in the octave a problem or a question (or questions), which the sestet then resolves or answers. This pattern provides a resolution to the speaker's thoughts, and thus tends toward a formal closure that offers assurance and hope. Sonnet 29 clearly follows this well-established pattern. In contrast, Whitman moves from a description of his suffering to a series of questions that he cannot answer and thus his "sonnet" lacks the closure that the traditional form leads the reader to expect. (In Robert Frost's sonnet "Design," the famous last line- "If design govern in a thing so small" - similarly deviates from the form's expected closure, leaving the reader in a state of unresolved uncertainty.)

"The standard way of constructing a Petrarchan sonnet," says Paul Fussell, "is to project the subject in the first quatrain; to develop or complicate it in the second; then to execute, at the beginning of the sestet, the turn which will open up for solution the problem advanced by the octave, or which will ease the load of idea or emotion borne by the octave, or which will release the pressure accumulated in the octave. The octave and the sestet conduct actions which are analogous to the actions of inhaling and exhaling, or of contraction and release in the muscular system. The one builds up the pressure, the other releases it; 
and the turn is the dramatic and climactic center of the poem, the place where the intellectual or emotional method of release first becomes clear and possible. From line 9 it is usually plain sailing down to the end of the sestet and the resolution of the experience."

The first half of "Hours Continuing Long" certainly builds up the pressure, but the second half, far from providing a resolution or release, as happens in Sonnet 29, continues the same repetitive structure as the first half, building up even more pressure. The "octave" contains six lines that begin with "Hours"; the sestet is similarly repetitive in its syntactic structure:

Is there even one other like me ...?

Is he too as I am now?

Does he too harbor his friendship silent and restless?

Does some stray reminder ... ?

Does he see himself reflected in me? (11. 8-12)

The most common pattern of the Petrarchan sonnet follows an emotional arc from problem to solution, or from question to answer, or (as in Shakespeare) from dejection to hope. The key image in Sonnet 29 is the lark rising from the sullen earth, soaring toward heaven's gate, an image that is the objective correlative of the speaker's soaring spirit when he remembers the young man. The movement of the poem is linear, in an ascending line from earth to the skies, the soaring flight of the lark figuring the emotional movement of the poem. In contrast, the repetitive pattern of Whitman's poem, as the title implies, suggests that the speaker is trapped in a static state of mind that he cannot break out of. The repetition of "hours" in the last two lines, echoing the first six lines, implies that Whitman-unlike Shakespeare's speaker-has not progressed beyond the state of "sullenness and suffering" described in the first six and a half lines. All he can do is imagine someone suffering like himself, repeating his sullen thoughts.

The reason that Whitman deviates from the conventional, expected pattern of the sonnet is that his poem, as the series of unanswered questions show, does not express the confidence, assurance and hope that we find in Shakespeare's Sonnet 29. ${ }^{9}$ The seven questions that make up the "sestet" of this re-formed sonnet are all questions for which Whitman has no answers. The hopelessness he expresses in the first half of the poem recalls a famous Renaissance sonnet that is part of the intertextual grid against which Whitman invites us to read his re-formed sonnet, namely Michael Drayton's "Since there's no help, come let us kiss and part." The octave of Drayton's famous poem suggests that the love affair is irretrievably over, and that there is no hope of the lovers reviving their former feelings for one another. But the sestet holds out the hope that 
the woman addressed by the speaker, "when all have given [Love] over, / From death to life ... mightst him yet recover." A similar possibility in Whitman's poem is strongly suggested by the depth of despair and hopelessness described in the first six and a half lines, paralleling the feelings of Drayton's speaker, but Whitman's sestet takes a different, unexpected "turn." Instead of imagining a "recovery" of his relationship with his beloved, as Drayton had done, or taking comfort from a remembrance of the beloved (as Shakespeare's speaker does), Whitman wonders if there is any other man in his "outcast state," as the last six lines shift the focus from the beloved to an imagined other, a double of Whitman. Consolation, if there is to be any, will come not from remembering the lover described in the first half of the poem, but from imagining the possibility of there being another man as dejected as himself, a brother in sullenness and suffering.

Biographical criticism of the poem identifies the young man with a young Irish stage driver named Fred Vaughan, with whom it is believed Whitman had an intense relationship in the late 1850s. Critics have also speculated that Vaughan may have been the inspiration for the "Live Oak, with Moss" sequence. ${ }^{10}$ If read biographically, these twelve "sonnet-like love poems" 11 record Whitman's dejection and despair over his failed relationship with Vaughan, who married and thereafter kept at best a tenuous relationship with Whitman. The failure of the relationship with Vaughan was doubtless a traumatic event for Whitman and may very well have occasioned the "Live Oak, with Moss" series. But there is no need to assume that "Hours Continuing Long" reflects Whitman's biography. It is, after all, a poem, not a journal entry. And its poetic status is in part conferred by its relationship to the sonnet form and specifically to Shakespeare's Sonnet 29. If the poem is read in terms of the conventions of the sonnet, its biographical elements take on a new significance. One reason that Whitman "turns" in the sestet to an imagined double of himself instead of anticipating a reunion with the beloved is that he realizes that there is little likelihood that his love for this man will be requited. The most likely reason is not that the man has broken off the relationship and chosen someone else (as Vaughan did), but that the man does not even know of the speaker's love for him, since the speaker has not declared it to him.

Once the poem is taken out of the original "Live Oak, with Moss" series and placed in the "Calamus" cluster, there is nothing in the first six lines to definitively indicate that the speaker's love for the man was ever reciprocated. Indeed, the echoes of Sonnet 29 suggest that his feelings are not reciprocated. A more likely scenario is that the beloved man knows nothing of the speaker's feelings for him. This does not mean, of course, that there is no biographical element in the poem at all —only that Whitman has reconstructed his biography to suit the rhetorical needs of the 
poem. It is the speaker's shame (and Whitman's), specifically mentioned in the poem ("I am ashamed"), which has prevented him from declaring his love, and so he wonders if there are countless other men in the same situation as him: men who, like him, are ashamed and lack the courage to declare "I am what I am" (as Shakespeare's speaker does in Sonnet 121). He is not imagining men who have loved and lost, but men who have never had the courage to declare "I am what I am."

My proposal to read "Hours Continuing Long" as a modified sonnet that responds to Shakespeare's Sonnet 29 gains additional support when we realize that this is not the only Whitman poem that both borrows the conventions of the sonnet form and echoes a particular sonnet. "When I Heard the Learn'd Astronomer," like a conventional sonnet, sets up in the first four lines (all of which begin with "When") a contrast between the analytic, mathematical study of the heavens and (in the last four lines) an alternative way of viewing and experiencing the awe of the cosmos. Not only does this poem borrow the bi-partite form of the conventional sonnet, it specifically echoes the form and language of Keats's famous sonnet "On First Looking into Chapman's Homer," which sets up a contrast between Keats before and after he read Chapman's translation of Homer. Just as Keats goes from the octave's imagery of familiar realestate, worldly principalities and travel around the Mediterranean to images of discovery-a new planet and a new ocean-Whitman takes us from the astronomer's analytic world of "proofs," "figures," "charts and diagrams," and precise mathematical measurement to a world that cannot be added, divided or measured. Not only does an astronomer appear in both poems, but Whitman's response to the starry heavens parallels the response of Balboa's men to the sight of the Pacific Ocean, even down to the repetition of the words "look'd" and "silent/silence" in the last two lines of both poems:

-and all his men

Look'd at each other with a wild surmise-

Silent, upon a peak in Darien. ${ }^{12}$

Whitman's poem ends:

In the mystical moist night-air, and from time to time,

Look'd up in perfect silence at the stars. $(L G, 271)$

Although "When I Heard the Learn'd Astronomer" is not a sonnet, the parallels with Keats's famous sonnet are, I would argue, relevant to our appreciation of the poem's form and meaning. Reading it as a re-formed sonnet makes us realize just how unexpectedly conventional and traditional Whitman's poem in fact is, as well as how much its originality de- 
pends on its deliberate deviance from a well-established generic form.

"[A] text is at its most informative," says Terry Eagleton, "when it deviates unpredictably from one of its codes, creating effects which stand out against this uniform background." ${ }^{13}$ It is certainly significant that the experience Whitman records in the last line is expressed, unexpectedly, in a deviant line of regular iambic pentameter: "Look'd up in perfect silence at the stars." Paul Fussell anticipated Eagleton's point in Poetic Meter and Poetic Form: "Many free-verse poems," he observes, "establish a non- or anti-metrical verbal continuum as a grid against which occasional metrical moments are perceived as especially forceful." As an example of this poetic practice, he cites "When I Heard the Learn'd Astronomer," which, he says, "devotes seven lines to establishing a loose 'sincere' quasi-prosaic grid as a field against which the final line of iambic pentameter emerges with special emphasis reinforcing the irony" (Fussell, 84). But it is not just the free-verse of the poem that provides an irregular metrical grid against which the final line of regular iambic pentameter emerges with special emphasis. It is also the regularity of the traditional sonnet, familiar to poet and reader alike, that provides a formal grid against which Whitman's deviations from the expected pattern, and particularly the contrast with Shakespeare's Sonnet 29, emerge with special emphasis.

Modifying the form of the traditional sonnet enabled Whitman to participate in literary tradition, but by alluding specifically to Shakespeare's Sonnet 29, he could also contrast his own "silence" with Shakespeare's explicit representation of a positive relationship between men. And while Shakespeare's sonnets provided Whitman with a precedent for writing about his own (sexual) experience, the tradition of modifying the sonnet form enabled him, to some extent, to depersonalize his experience and hence to move from the personal to the social and the political. The shift from the friend who has forsaken him to the imagined double of himself suggests that this poem is not only an expression of Whitman's personal situation, the usual subject matter of a love sonnet, but also a political meditation on the absence of a community of similar men who experience the same feelings as Whitman does. This shift from the psychological to the social is the main way in which Whitman's poem deviates from the subject matter of both the Petrarchan love sonnet and Shakespeare's Sonnet 29. Whereas the traditional love sonnet is personal and psychological, Whitman's reformed sonnet has a social dimension absent from the conventional love sonnet. In order to make his "Sullen and suffering hours" bearable, Whitman tries to imagine another "outcast" man who is also "Sullen and suffering" like himself-and suffering for the same reason.

The contrast between the sestet of Shakespeare's sonnet and the last five and a half lines of Whitman's poem now becomes clear. For Shake- 
speare's speaker, the remembered love of the youth is sufficient to lift his spirits, like the lark arising from sullen earth. But for Whitman, the remembered love of his friend-"I believe I am never to forget!"- can provide no such benefit. What ultimately troubles Whitman is not that he has lost his friend but that he has to "harbor his friendship silent." The unacceptability of that silence, rather than the taboo on writing about a same-sex relationship, likely explains his decision to exclude the poem from later editions of Leaves of Grass. Whitman's confession of silence and shame, an acknowledgement of political impotence, later became inconsistent with the political aims he wanted the "Calamus" poems to serve.

After its first and only appearance in the 1860 edition of Leaves of Grass, "Hours Continuing Long" came to seem simply too autobiographical and confessional for Whitman. In the mid-nineteenth century, it was widely believed that Shakespeare's sonnets, like Petrarch's and Dante's, were autobiographical, and that the sonnet (despite the political sonnets of Milton and Shelley) was primarily a form of self-expression. Wordsworth, in his famous sonnet beginning "Scorn not the sonnet," defends the form on the grounds that "with this Key / Shakespeare unlocked his heart." ${ }^{14}$ But Whitman wanted to do more than unlock his heart. By 1876, Whitman explicitly saw the "Calamus" poems as political poems: "[I]mportant as they are in my purpose as emotional expressions for humanity, the special meaning of the Calamus cluster of Leaves of Grass ... mainly resides in its Political significance. In my opinion it is by a fervent, accepted development of Comradeship, the beautiful and sane affection of man for man, latent in all the young fellows, North and South, East and West - it is by this, I say, and by what goes directly and indirectly along with it, that the United States of the future, (I cannot too often repeat, ) are to be most effectually welded together, intercalated, anneal'd into a Living Union" ( $L G, 751)$.

In writing about a same-sex relationship in "Hours Continuing Long," Whitman was writing about a subject for which there was no precedent or model in American literature. And since he lacked an American precedent, it is hardly surprising that he should have turned to a European one. Nor is it surprising that he should turn to one of the few literary models that he could count on many of his readers being familiar with, Shakespeare's Sonnet 29. The Shakespearean model of a sonnet addressed to a beautiful youth might to some extent provide a literary precedent that would legitimize the taboo subject matter of "Hours Continuing Long," but Whitman did not just want to write about his own private experience, and thus the conventional love sonnet, as he inherited it, was unsuitable for his purpose. The inadequacy of the form for his purpose is reflected in his decision to re-form it from a predominately autobiographical form into a vehicle through which he 
could express not only his own sullenness and suffering, but also-and more importantly - his political protest against having to suffer, like countless others, in silence. But that protest was, at best, tepid in "Hours Continuing Long"-most of the poetry is in the sullen suffering. So when he eventually came to value the "Calamus" poems primarily for their "Political significance," it is understandable why he removed "Hours Continuing Long" from later editions of Leaves of Grass: the reason was not so much that its autobiographical content was too explicitly sexual but that its merely personal "plaintive cries," too reminiscent of Shakespeare's "bootless cries," were insufficiently political.

\section{University of Regina}

\section{NOTES}

1 Joel Myerson, ed., Whitman in His Own Time: A Biographical Chronicle of His Life, Drawn from Recollections, Memoirs, and Interviews by Friends and Associates (Iowa City: University of Iowa Press, 1991), 234.

2 Quoted in Alan Helms, "Whitman's 'Live Oak with Moss," Robert K. Martin, ed., The Continuing Presence of Walt Whitman: The Life after the Life (Iowa City: University of Iowa Press, 1992), 186. Whitman wrote his description of the sequence on the back of an early manuscript of the title poem of "Live Oak, with Moss."

3 Whitman's poem is untitled in the "Live Oak, with Moss" sequence (where it is numbered "VIII") and remains untitled in the 1860 Leaves of Grass, where it is numbered "9." In the 1867 edition of Leaves, Whitman gave the "Calamus" poems titles, usually using the opening line or phrase of each poem. I have followed his lead in calling this poem, which he never reprinted after 1860, "Hours Continuing Long."

4 Justin Kaplan, Walt Whitman: A Life (New York: Simon and Schuster, 1980), 236.

5 A too rigid definition of the sonnet form has prevented our reading "Hours Continuing Long" as a response to the sonnet and specifically Shakespeare's sonnets. In spite of what we were taught in high-school English classes, and notwithstanding the definitions of it in countless glossaries of literary terms, the sonnet is not as restrictive a form as is usually supposed, which partly explains its enduring power. Although the prototypical form of the sonnet consists of fourteen lines arranged in a predetermined pattern of rhyme schemes and groupings of lines (octave and sestet, four quatrains and a concluding couplet), not all sonnets contain fourteen lines (including some of Shakespeare's) and there are many examples of modern unrhymed sonnets. Hopkins experimented with a shortened form of the sonnet he called "curtal sonnets," as well as with 18- and 20-line "sonnets." Robert Hayden's great unrhymed sonnet "Frederick Douglass," composed in the tradition of the political sonnets of Milton and Shelley, reverses the division of the traditional sonnet, devoting only six lines to the "octave" and eight to what in a conventional sonnet would be the sestet, the turn coming at the end of line six. And in Sandra Gilbert's satirical, anti-Petrarchan "Sonnet: The Ladies' Home Journal," there are just two rhymes (including a Shakespearean couplet at the end), and a "turn" that comes unconventionally in the middle of line 11 . Genres survive through adaptation, and the sonnet has proved to be perennially adaptive. 
6 William Shakespeare, "Sonnet 29," Shakespeare's Sonnets, ed. Stephen Booth (New Haven: Yale University Press, 1977), 27-28.

7 “[Hours Continuing Long]," Leaves of Grass: Comprehensive Reader's Edition, ed. Harold W. Blodgett and Sculley Bradley (New York: New York University Press, 1965), 596-597.

8 Paul Fussell, Poetic Meter and Poetic Form, revised edition (NewYork: Random House, 1979), 116.

9 Helms sees a similar contrast between "Hours Continuing Long" and Sonnet 121: "At the heart of this poem, Whitman echoes Shakespeare's Sonnet 121 ('I am that I am') in which Shakespeare is 'vile esteemed' by those who 'count bad what I think good.' But Shakespeare's self-definition is affirmative and defiant in the face of such judgment, whereas in Whitman the judgment combines with his pain at being abandoned in a way that defeats him" (190).

10 See Charley Shively, Calamus Lovers: Walt Whitman's Working Class Camerados (San Francisco: Gay Sunshine Press, 1989), 36-50.

11 Ed Folsom and Kenneth M. Price, Re-Scripting Walt Whitman: An Introduction to His Life and Work (Oxford: Blackwell, 2005), 62.

12 John Keats, “On First Looking into Chapman's Homer," Complete Poems, ed. John Stillinger (Cambridge, MA: Harvard University Press, 1982), 34.

13 Terry Eagleton, How to Read a Poem (Oxford: Blackwell, 2007), 55

14 William Wordsworth, "Scorn Not the Sonnet," in Last Poems, 1821-1850, ed. Jared Curtis (Ithaca: Cornell University Press, 1999), 82. 